\title{
W POGONI ZA NOSTALGICZNYM MITEM ROCKOWEGO BOOMU. FESTIWAL MUZYKÓW ROCKOWYCH W JAROCINIE JAKO MIEJSCE PAMIĘCI
}

\author{
IN SEARCH OF NOSTALGIC MYTH OF ROCK MUSIC BOOM: \\ THE ROCK MUSICIANS' FESTIVAL IN JAROCIN \\ AS A REALM OF MEMORY
}

Marek Jeziński*$$
\text { ABSTRAKT }
$$

$\mathrm{W}$ artykule boom polskiego rocka lat 80 . XX wieku interpretuję jako sferę nostalgicznej mitologii, a zjawisko „pokolenia Jarocina” i Festiwal Muzyków Rockowych w Jarocinie traktuję jako miejsca pamięci (lieux de memoire, zgodnie $\mathrm{z}$ definicją Pierre'a Nory) o naturze politycznej. Festiwal w Jarocinie (z okresu z pierwszej połowy lat 80.) rozpatrywać obecnie można jako swoistą formę obecności przeszłości w działaniach podejmowanych współcześnie, mających na celu uobecnienie i reprodukcję ważkich dla społeczeństwa polskiego wartości. Za istotne dla tak rozumianego miejsca pamięci uznać należy jarocińskie rytuały, wspólnotę tworzoną przez muzyków i publiczność Festiwalu, wydarzenia, ludzi i miejsca, które wiążą się z Jarocinem. Co istotne, Festiwal stał się doświadczeniem formacyjnym dla generacji młodych ludzi,
\end{abstract}

In the paper the boom of Polish rock music of the $1980^{\mathrm{s}}$ is interpreted as a sphere of nostalgic mythology, and the phenomenon of the "Jarocin generation" and the Rock Musicians' Festival in Jarocin is considered the realm of memory (lieux de mémoire, according to the definition of Pierre Nora) of political nature. The Jarocin Festival (from the first half of the 1980s) can now be seen as a kind of presence of the past in today's activities, aimed at the presentation and reproduction of several values important for the Polish society. Such a realm of memory consists of Jarocin rituals, a community created by musicians and the audience of the Festival, events, people and places related to Jarocin. More importantly, the Festival has become a formative experience for the generation of young people, interacting in a grouping fashion for many (mostly subcultural)

* Uniwersytet Mikołaja Kopernika w Toruniu, Wydział Politologii i Studiów Międzynarodowych. 
oddziałującym w sposób grupotwórczy dla wielu środowisk (przede wszystkim subkulturowych) i jednocześnie okazał się jednym $z$ istotnych czynników prowadzących do erozji niedemokratycznego systemu politycznego w Polsce.

Słowa kluczowe: miejsca pamięci, boom polskiego rocka, Festiwal Muzyków Rockowych w Jarocinie communities, and simultaneously, it has become one of the important factors leading to the erosion of the non-democratic political system in Poland.

Keywords: realms of memory, boom of Polish rock music, Rock Musicians' Festival in Jarocin

$\mathrm{W}$ artykule niniejszym spojrzę na boom polskiego rocka lat 80 . XX wieku jako na sferę nostalgicznej mitologii i szczególnego rodzaju miejsce pamięci. Do takich kategorii kulturowych należą: „pokolenie Jarocina” i „festiwal w Jarocinie”, „Lista Przebojów Trójki” i „Program Trzeci Polskiego Radia”, „Lista Przebojów Rozgłośni Harcerskiej” i „Radio Nieprzemakalni”, „bunt rockowych artystów”, „underground Trzeciego Obiegu” oraz najpopularniejsi wykonawcy tego okresu jako hasła wywoławcze lat 80 ., obecne w zbiorowej pamięci. Co istotne z punktu widzenia nauk o polityce, miejsce pamięci, jakim jest Jarocin, sytuowany jest w kontekście istotnych wydarzeń politycznych owego okresu, takich jak stan wojenny, kryzys ekonomiczny oraz niewydolność władzy ostatniej dekady istnienia PRL. Milcząco w pracy tej zakładam, że rock i konteksty jego funkcjonowania w Polsce (jak choćby: festiwale, koncerty, wydawnictwa fanowskie, oddolny ruch III obiegu kulturowego) były zjawiskami natury politycznej: ludzie tworzący ową rockową kulturę (muzycy, animatorzy życia artystycznego, fani, publiczność festiwali) stali się swego rodzaju ruchem politycznego rodzaju, a postulaty przez nich głoszone, jak choćby kontestacja systemu, sprzeciw wobec władzy, konflikt pokoleń, pochwała wolności jednostkowej, etc. miały w realiach PRL wymiar manifestu silnie nacechowanego politycznie i były poprzez to jednym $\mathrm{z}$ istotnych elementów, powodujących w substancjalny sposób erozję niedemokratycznego systemu władzy w drugiej połowie dekady lat 80 .

Powrót do tego, co przeszłe, ma w przypadku rockowej kultury w Polsce konkretne odniesienie - to lata 80 . XX wieku uznawane mogą być za najbardziej witalny okres w historii polskiej muzyki popularnej. W polskiej mitologii muzycznej to okres „końcowego Gierka” (1980) i czas stanu wojennego zapisały się jako okres bezprecedensowego boomu muzycznego, którego korzenie tkwią co prawda w poprzedniej dekadzie, jednak to z pierwszą połową lat 80. kojarzymy największe gwiazdy polskiego rocka oraz najważniejsze w nim zjawiska. W arty- 
kule zanalizuję Festiwal Muzyków Rockowych w Jarocinie (w okresie z pierwszej połowy lat 80.) jako miejsce pamięci (lieux de memoire), a więc swoistą formę obecności przeszłości w działaniach podejmowanych współcześnie, mających na celu uobecnienie i reprodukcję wartości istotnych dla danej części społeczeństwa.

\section{MIEJSCA PAMIĘCI}

Miejsca pamięci to koncepcja spopularyzowana przez francuskiego historyka Pierre'a Norę w siedmiotomowej wydawanej na przestrzeni 1984-1992 pracy Les Lieux de Mémoire (1984; wyd. ang. pt. Realms of Memory). Zakłada on, że: "A lieu de mémoire is any significant entity, whether material or non-material in nature, which by dint of human will or the work of time has become a symbolic element of the memorial heritage of any community" (Nora, 1996), a więc miejsca, w których "memory crystallizes and secretes itself" (Nora, 1989). Francuski historyk wskazuje na trzy rodzaje takich właśnie społecznych tworów, które można uznać za przykłady lieu de mémoire, występujące w większości kultur, przy czym mogą one mieć charakter publiczny oraz prywatny (a więc ograniczony, przykładowo, do jednej tylko rodziny):

a) miejsca, a więc konkretne fizyczne lokalizacje (muzea, katedry, pałace, pomniki, cmentarze, pozostałości antycznych ruin), przykładem będzie tu Muzeum Powstania Warszawskiego, Zamek Królewski w Warszawie, pomnik Mikołaja Kopernika w Toruniu, katedra na Wawelu;

b) idee i praktyki kulturowe (rytuały, ceremonie upamiętniające, inskrypcje i motta) jako przykłady można tu wskazać: polskie ceremonie rocznicowe 11 listopada, upamiętniające odzyskanie niepodległości;

c) obiekty fizyczne (pamiątki - np. rodzinne, teksty ksiąg, podręczniki, symbole, emblematy), których egzemplifikacjami będą podręczniki szkolne, rodzinne zdjęcia i przedmioty odziedziczone po przodkach, pamiątki pochodzące $\mathrm{z}$ minionych czasów, jak choćby cenione w pierwszych dekadach XXI wieku przedmioty codziennego użytku z czasów PRL (wzornictwo, meble, samochody, płyty winylowe, radioodbiorniki, telewizory, gramofony, komiksy, książki, pocztówki etc.).

Wokół miejsc pamięci rozwija się, co zrozumiałe, cały szereg rytuałów, narracji i mitologii, które są przekazywane społecznie. Ich główną rolą jest budowanie tożsamości grupowej, integracji i identyfikacji - a więc istotnych czynników grupotwórczych w socjologicznym znaczeniu: stanowią one ośrodki skupienia, 
centra, wokół których rozwijane są narracje dotyczące jednostek, grup i całych społeczeństw.

Jan-Werner Müller pokazuje istotne rozróżnienie na pamięć typu „zbiorowego” lub „narodowego” oraz pamięć „,indywidualną”. Jak zauważa on w swej pracy: „The latter refers to the recollection of events which individuals actually lived through. The former establishes a social framework through which nationally conscious individuals can organize their history. It is this national-collective memory and national identity which are mutually constitutive. This type of memory influences, but also sometimes conflicts with, individual memories. Here memory - like identity - is always in danger of giving rise to absolute moral claims and to becoming non-negotiable" (Müller, 2002). "Collective memory is always the outcome of a series of ongoing intellectual and political negotiations; it is never a unitary collective mental act. However, precisely because collective memory is not a property, but an ongoing process, it is also above all collective or national memory which is most susceptible to be influenced by politicians, journalists and historians. «High politics» understood as presidential speeches and other symbolic gestures by national representatives matters enormously for memory" (Müller, 2002).

Oznacza to istotną konsekwencję: pamięć, pamiętanie i wspomnienia nie są dane jednostkom i grupom raz na zawsze i w jednakowej formie. Podlegają one procesom redefinicji, repetycji, a więc ciągłego powtarzania, które - z jednej strony - umożliwia pamiętanie jako takie (a więc fakt, że w ogóle pamiętamy cokolwiek jako jednostki), a z drugiej - umożliwia formatowanie i zmienianie wspomnień, nawet tych, uznawanych za niezmienne i nienaruszalne. Doświadczenia życiowe jednostek oraz społeczne konteksty ich działań i interakcji prowadzić mogą do tego, że poddawana oddziaływaniom innych ludzi (rodzina, znajomi, media, system polityczny) jednostka modeluje swoje nastawienie do przeszłości i może - jako konsekwencja działań społecznych - zmienić swoje wspomnienia lub odczuwać dyskomfort w zderzeniu ze „społecznym dowodem słuszności” w sytuacji, gdy jakieś wydarzenia są pamiętane przez danego człowieka inaczej, niż podawane jest to np. w mediach.

Podkreślmy w przytoczonej powyżej koncepcji miejsc pamięci, po pierwsze, symboliczny charakter miejsc pamięci, po drugie, społeczny aspekt powstawania takich miejsc, oraz po trzecie, ich materialny lub niematerialny charakter. Dzieje się tak dlatego, że społeczności potrzebują symbolizacji własnych wartości tworzonych przez społeczność i dla niej, a więc definiowanych doraźnie i za pomocą symboli interpretowanych w bieżącym użyciu dla określonych celów. 
Żadne miejsce czy symbol nie staje się miejscem pamięci samo z siebie - jest nim tylko i wyłącznie $\mathrm{z}$ woli społeczności, która w danym momencie historycznym uznaje dane miejsce i symbol za wartościowe ze społecznego punktu widzenia. Pamięć ludzka potrzebuje materialnego korelatu, jakim zawsze jest symbolizacja wartości. Dzieje się to na zasadzie wizualizacji wartości, która jest dla odbiorcy istotna, symboliczna, a jednocześnie materialna. I tak: godło państwowe, hymn, flaga, specjalne miejsca istotne dla każdej społeczności posiadają moc symboliczną, wzmacnianą przez materialny charakter symbolizowanej wartości. Miejsce pamięci musi wpisać się w zbiorową świadomość społeczeństwa - najczęściej będą to budowle i fizycznie identyfikowalne miejsca (pomnik, budynek, muzeum). Do miejsc pamięci w tej koncepcji należą także - i ta szeroka interpretacja będzie użyteczna w interesującym mnie kontekście - zachowania ludzkie, spotkania, wydarzenia, osoby, symbole, kolory, tradycje (np. kulinarne) czy specyfika języka. Część z nich jest trudno definiowalna w kontekście symbolicznym i na ogół nieprzekładalna na inne systemy kulturowe, jednak potwierdzana jako istotne $\mathrm{z}$ symbolicznego punktu widzenia miejsca poprzez odpowiednie praktyki kulturowe. Poprzez miejsca pamięci społeczeństwo sakralizuje samo siebie - dostosowując ich symboliczną interpretację do bieżącej praktyki w życiu publicznym. Założyć można, że władze polityczne, niezależnie od obowiązującego w danym państwie reżimu, chętnie wykorzystują miejsca pamięci do wzmacniania postaw definiowanych przez siebie jako właściwe (np. aktywność obywatelska, nacjonalizm). Stąd nie dziwi proces zawłaszczania przez rządzących miejsc pamięci jako ośrodków skupienia określonych postaw. Jak zresztą zaznacza Nora (1996): "In the past, then, there was one national history and there were many particular memories. Today, there is one national memory, but its unity stems from a divided patrimonial demand that is constantly expanding and in search of coherence".

Społeczeństwo według własnych zasad organizuje postrzeganie przeszłości (wydarzeń, ludzi, symboli) i samego faktu zbiorowej pamięci: pamiętanie jest procesem społecznym, podlegającym ciągłym redefinicjom, a więc zmianom kontekstowym. To, w jaki sposób pamiętamy i co pamiętamy, zależne będzie od uwarunkowań społecznych i aktualnych oczekiwań w zakresie podzielania wspólnej definicji sytuacji: pewne wydarzenia zyskują status istotności społecznej, inne tracą go wraz z upływem czasu. Co istotne, jak w Les Cadres sociaux de la memoire zakładał Maurice Halbwachs (1925), pamięć indywidualna zanurzona jest w kontekście społecznym i to właśnie od tego ostatniego zależy zakres indywidulanego pamiętania oraz kształtu wspomnień istotnych dla każdej 
jednostki. To, w jaki sposób pamiętamy, zależne jest na ogół od kontekstów społecznych - miejsc, wrażeń, doświadczeń lokowanych przede wszystkim w kontekstach relacji międzyjednostkowych.

Zgodzić się tu można z Pierre Norą, że: „Pamięć i historia nie są bynajmniej synonimami, jesteśmy świadomi, że wszystko je dzieli. Pamięć jest życiem, bezustannie podtrzymywanym przez grupy żyjących i z tego względu podlega ciągłej ewolucji, otwartej na dialektykę spełnienia i amnezji, nie troszcząc się o kolejne deformacje, podatność na zabiegi instrumentalizacyjne czy manipulacyjne. Historia natomiast jest rekonstrukcją zawsze problematyczną i niekompletną tego, czego już nie ma” (Nora, 1984).

Jak zaznacza Maria Delaperrière (2013), w odróżnieniu od absolutnej pamięci, historia zawsze mieć będzie charakter relatywny. Oznacza to, że historia, jako fenomen społeczny, zderza się z fenomenem jednostkowym, jakim jest pamięć. Dzieje się tak dlatego, że wiedza społecznie tworzona i interpretowana, jaką jest historia, pisana jest zawsze z określonego punktu widzenia i poddawana jest manipulacji definiującej to, co istotne, podkreślającej to, co z określonego stanowiska warte jest uwypuklenia. Inaczej dzieje się z pamięcią - jest ona definiowana tylko na użytek danej jednostki, jednak osoba ta dokonuje projekcji własnego doświadczenia na całość życia społecznego, uznając, że jej własne doświadczenia pokrywają się z doświadczeniami całej grupy ${ }^{1}$.

\section{JAROCIN - MIEJSCE PAMIĘCI}

Jarocin jako miejsce pamięci łączy w sobie kilka poziomów koncepcji miejsca pamięci wyróżnionych przez Norę. Stąd można uznać, że jest to hasło niestandardowe w kontekście tej koncepcji, a co za tym idzie - określmy tego typu zjawisko meta-miejscem pamięci, w którym łączymy poziomy realny i sym-

1 Miejsca pamięci to koncepcja szeroko dyskutowana we współczesnej humanistyce - na wiele sposobów rozumiana i interpretowana. Za ważne głosy w tej dyskusji, oprócz prac przywoływanych szczegółowo w tekście, uznać należy takie pozycje, jak: Cultural Memory and Early Civilization: Writing, Remembrance, and Political Imagination, J. Assman, 1992, Cambridge: Cambridge University Press; Przedstawianie przeszłości. Uwagi na temat mitu i historii, K. Hastrup, 1997, Konteksty. Polska Sztuka Ludowa, 1-2/1997, 22-28; Past is the Foreign Country, D. Lowenthal, 1988, Cambridge: Cambridge University Press; Technologies of Memory in the Arts, L. Plate, A. Smelik (red.), 2009, New York: Palgrave Macmillan; The Discovery of the Past. The Origins of Archaeology, A. Schnapp,1996, London: British Museum Press. 
boliczny, fizycznej przestrzeni i idei. Co więcej, Jarocin i Festiwal Muzyków Rockowych podlegają konsekwentnie mitologizacji - zarówno w odniesieniu do przeszłości, jak i teraźniejszości. Działania podejmowane wokół festiwalu odnoszą się wprost do lat 80 . XX wieku, ale widać też kontynuację osadzoną w teraźniejszości (Spichlerz Polskiego Rocka) oraz, co nie mniej istotne, mitologizacja ta dokonywana jest przez wiele podmiotów nadawczych i przy pomocy połączenia działań wykorzystujących tradycyjne media (filmy, książki) oraz nowe media (strony www.).

\section{ZAŁOGA MUSI BYĆ JAK PALCE JEDNEJ RĘKI. \\ JAROCIŃSKA KONTRKULTURA: BUNT - WOLNOŚĆ - WSPÓLNOTA}

Na mitologię Jarocina jako miejsca pamięci, składa się wiele czynników: muzyka prezentowana podczas festiwalu, atmosfera panująca podczas imprezy, zachowania ludzi oraz podzielane powszechnie poczucie pokoleniowej wspólnotowości i buntu przeciwko narzuconym odgórnie autorytetom politycznym i społecznym. Te elementy pojawiają się $\mathrm{w}$ wywiadach $\mathrm{z}$ uczestnikami festiwalu: muzykami, organizatorami czy widzami. Festiwalowy Jarocin stawał się podczas imprezy swoistym grupotwórczym ośrodkiem skupienia w znaczeniu socjologicznym dla grupy o charakterze krótkotrwałym o rekrutacji typu dobrowolnego. Można bowiem w tym przypadku wyróżnić takie konstytutywne dla grupy społecznej elementy, jak:

- znacząca liczebność grupy, tu jednak należy zauważyć, że grupa „Jarocin” złożona była z wielu mało licznych - od kilku do kilkunastu osób - pod-grup (jak np. mieszkańcy jednego namiotu);

- występowanie rozpoznanego społecznie jednego istotnego ośrodka skupienia;

- wytworzenie się świadomości wspólnotowej, a więc poczucie kolektywnego „my”;

- grupa działała na podstawie zespołu społecznie podzielanych wartości i norm konstytuujących tę zbiorowość i typowych dla niej;

- członkowie grupy wchodzą ze sobą w liczne i intencjonalnie postrzegane interakcje i stosunki społeczne w oparciu o podzielaną definicję sytuacji ludzie ustosunkowują się do siebie nawzajem;

- zaistnienie elementów kontroli społecznej, funkcjonującej jako przejawy kontroli dwóch rodzajów: zinstytucjonalizowanej, a więc formalnej, egze- 
kwowanej przez powołane do tego celu siły porządkowe pracujące przy Festiwalu i skierowane do miasta oddziały Milicji Obywatelskiej i ZOMO, oraz nieformalnej, egzekwowanej przez samą młodzież.

Interesującym zjawiskiem jest kwestia ciągłości grupy - choć udział w grupie tego rodzaju przejawia się jako konkretnie wyznaczona w czasie obecność na Festiwalu, mieście czy polu namiotowym, co sprawia, że mamy do czynienia z grupą krótkotrwałą, zmieniającą skład podczas samej imprezy oraz w znaczącym stopniu zmieniającą skład podczas kolejnych edycji. Stąd, między innymi, mowa we wspomnieniach uczestników o gradacji doświadczeń Jarocina: z 1984 rokiem jako punktem kulminacyjnym i kolejnymi edycjami o coraz niższym poziomie muzycznym i niżej cenionymi pod względem atmosfery, wspólnotowości, pokoleniowego buntu młodzieży przeciw generacji rodziców. Z drugiej jednak strony uczestnicy kilku edycji Jarocina podkreślają swego rodzaju ciągłość doświadczenia festiwalowego: wspólnota tworząca się podczas kilku dni wakacji może w niektórych środowiskach trwać w kolejnych miesiącach, mimo że ograniczona pod względem kontaktów interakcyjnych i intensywności wspólnego spędzania czasu, z czego wynika względne (jednak istotne jakościowo) poczucie zubożenia relacji międzyludzkich pod względem ich wartości, intensywności i w konsekwencji - poczucia kolektywnego 'my' („w domu, w naszej miejscowości - to nie to samo, co na Festiwalu”). Podobnie tworzenie się wspólnotowości wokół pewnego podzielanego społecznie zespołu wartości i norm: przejawiające się jako i wzmacniane poprzez wspólne bycie ze sobą, liczne rozmowy na temat muzyki i występów zespołów obejrzanych podczas Festiwalu oraz wspólne słuchanie radia nadającego relacje $\mathrm{z}$ imprezy lub audycji poświęconych specjalnie Festiwalowi Muzyków Rockowych, jak to miało miejsce w przypadku Radia Nieprzemakalnych - audycji w Programie IV Polskiego Radia.

Jarociński Festiwal Muzyków Rockowych wspominany jest z dzisiejszej perspektywy jako swoista oaza wolności w świecie zdominowanym przez ideologię tłamszącą wolność jednostki. Ten aspekt wolności i wspólnotowości pojawia się jako główny wątek wspomnieniowy w wypowiedziach muzyków, organizatorów i uczestników Festiwalu. Muzycy wspominający jarociński festiwal, atmosferę na nim panującą i jego publiczność, stwierdzali:

Krzysztof Grabowski: „Ja te pierwsze Jarociny kojarzę z poczuciem wspólnoty. Ci wszyscy ludzie przyjeżdżali z najdalszych zakątków kraju i mogli zobaczyć, że nie tylko oni są świrami, odmieńcami, bo takich świrów jest kilka, kilkanaście tysięcy. I wtedy utrwalało się przekonanie, że to, co robię, jest w porządku, bo nie tylko ja to 
robię, robią to też inni. I kontakty między ludźmi zaowocowały wieloma ważnymi rzeczami, jak wydawnictwa niezależne, fanziny, kasety z muzyką. Publiczność była zatem bardzo fajna, ale do czasu” (Grabowski, 2016);

Tomasz Budzyński: „A najważniejszą rzeczą było to, że nie było barierek między sceną a publicznością. Czuliśmy, że jakby wszyscy..., że jesteśmy taką wspólnotą. Czuło się więź. Publiczność i zespół to była jedna banda" (Gnoiński, Gajczak, 2016);

Dariusz Dusza: „Zagrałeś koncert, szedłeś między ludzi, siadałeś na kocyku i sobie oglądałeś. Przychodzili ludzie «a fajnie zagraliście». Nie było barierek. (...) Teraz siedzisz w domu, masz wszystko po prostu, bez ruszania tyłka. A wtedy? Jarocin był wtedy jedynym... był takim polskim YouTubem. Z tym, że na żywo" (Gnoiński, Gajczak, 2016);

Olaf Deriglasoff: „Zobaczyłem siłę tłumu... przerażającą... fizyczną siłę tłumu. Energia była - aż buzowało od tej energii. To wszystko w powietrzu było elektryczne. I rzeczywiście, ten system miał się czego bać. Naprawdę" (Gnoiński, Gajczak, 2016);

Andrzej Nowak: „TSA było pierwszym zespołem, który złamał te straszne komunistyczne mury dzielące prawdę od kłamstwa. I ta muzyka miała tak potężną siłę, że ten mur zmiotła jednym uderzeniem. Myśmy wyszli jak wolni ludzie. Myśmy nie mieli skrupułów. Żadnych. Ludzie oczekiwali prawdy ze sceny, a myśmy ją dali” (Gnoiński, Gajczak, 2016).

\section{TO NIECH CIĘ ZGNIOTA W TEJ BUDZIE. JAROCIŃSKIE RYTUAŁY}

Dodatkowo, nakładając na te relacje kwestię dychotomicznego podziału karnawał - codzienność, a więc znane z pism Emila Durkheima rozróżnienie na sfery sacrum i profanum, jednostka poddawana jest innym uwarunkowaniom społecznym, co wynika ze specyfiki rytuału jako swoistego działania społecznego (uczestnictwo w festiwalu rockowym można zakwalifikować jako egzemplifikację jednocześnie rytuału typu kalendarzowego, rytuału wymiany i rytuału święta - odwołując się do typologii Catherine Bell, 1997). Oddziaływanie na 
jednostkę sfery karnawału, święta czy poczucia doświadczenia sacrum dodatkowo bywa w sytuacjach festiwalowych wzmacniana możliwością wytworzenia się rytualnego communitas, a więc szczególnego poczucia wspólnotowości, związanego ze wspólnym braniem udziału w rytuale i wynikającym z niego spłaszczeniem hierarchii statusów społecznych. Można uznać, że w „młynie” pod sceną pogujący uczestnicy koncertu przeżywają to samo, doświadczają tych samych emocji i są zrównani pod względem statusów społecznych, osiągając communitas typu spontanicznego według terminologii Victora Turnera (2010). Oznacza to dekompozycję struktury społecznej w rytualnych działaniach, struktury - wyznaczającej perspektywę poznawczą jednostek w sytuacjach pozarytualnych, co Turner (2010) nazywa antystrukturą: sztywna struktura społeczna, zakorzeniona w społeczności i rozpoznana jako właściwy sposób dystrybucji statusów społecznych, zostaje czasowo zawieszona, podobnie jak zestaw ról przypisanych jednostkom. W takich sytuacjach społecznych relacje między jednostkami nabierają szczególnego znaczenia: dochodzi do typowych dla stanu communitas zachowań prospołecznych, często niemających miejsca w relacjach międzyludzkich, typowych dla „normalnego” zestawu zachowań charakterystycznych dla danego społeczeństwa (a więc pochodzących ze sfery profanum, codzienności). Typowe w warunkach festiwalowych zachowania należące do tego typu działania społecznego, to przykładowo, częste dzielenie się żywnością, napojami, pieniędzmi czy proponowanie miejsca noclegowego. W takich warunkach struktura społeczna bywa zawieszana, a podziały klasowe, występujące wszak we wszystkich społeczeństwach, ulegają marginalizacji.

Działania rytualne odbywane podczas Festiwalu można podzielić, rozpisując je na konkretnych aktorów biorących udział w ceremoniach: z jednej strony, to rytuały związane z występującymi muzykami i organizatorami Festiwalu, z drugiej zaś - związane z publicznością i jej zachowaniami podczas koncertów. Można je ująć jako:

zachowania zespołów i organizatorów:

- przesłuchania / eliminacje w JOK,

- kwalifikacje na podstawie nadesłanych kaset,

- koncerty na scenach festiwalowych;

zachowania publiczności:

- taniec podczas koncertów (pogo, młyn),

- głosowanie w konkursie publiczności,

- rytuały akceptacji/odrzucenia grających zespołów,

- obrzut. 
Zauważmy, że zachowania organizatorów i muzyków grających na Festiwalu podlegały silnej rytualizacji - zarówno podczas trwania samej imprezy, jak i na wiele tygodni przed nią. O ile sam koncert rockowy jest dobrze rozpoznanym w kategoriach rytuału działaniem (w Jarocinie odbywały się koncerty w JOK oraz w latach późniejszych - w amfiteatrze na Małej Scenie i na stadionie Duża Scena), o tyle kilka słów komentarza warto poświęcić rytuałom związanym z kwalifikowaniem zespołów do jarocińskiego festiwalowego konkursu. $\mathrm{W}$ kolejnych latach mieliśmy do czynienia $\mathrm{z}$ wieloetapowymi działaniami rytualnymi, mającymi na celu wyłonienie zespołów występujących podczas imprezy. Ponieważ na jarocińskiej scenie mógł zagrać każdy polski wykonawca, który zgłosił się do konkursu, przeprowadzano eliminacje. Walter Chełstowski i jego współpracownicy lub zaproszeni przezeń eksperci (muzycy, managerowie i dziennikarze muzyczni) przesłuchiwali nadesłane przez muzyków kasety z nagranymi materiałami, pochodzącymi najczęściej z prób lub koncertów w lokalnych domach kultury. Nazwy wyłanianych tą drogą zespołów podawane były do publicznej wiadomości w programach radiowych. Część grup niezakwalifikowanych do koncertów decydowała się na przyjazd do Jarocina i wzięcie udziału w eliminacjach na scenie Jarocińskiego Ośrodka Kultury - muzycy grali jeden lub dwa utwory jako wizytówkę swojego stylu i na tej podstawie byli oceniani przez jury (Chełstowski i jego współpracownicy), podejmujące decyzję o kwalifikacji. Występom tym towarzyszyło napięcie emocjonalne i chęć artystycznego sprawdzenia się przed publicznością - grupy przyjeżdżały z całego kraju po to, by zagrać w eliminacjach, a większość z nich nie zostawała zakwalifikowana do występu na właściwym Festiwalu. Niezależnie od eliminacji kierownictwo imprezy zapraszało uznane zespoły w charakterze gwiazd oraz młode debiutujące grupy, które ich zdaniem powinny wystąpić na FMR (np. na podstawie obejrzanych gdzie indziej koncertów).

Niezwykle interesujące stały się rytuały akceptacji lub odrzucenia grających zespołów podczas koncertów festiwalowych. Ponieważ największą część publiczności FMR stanowiły grupy wielbicieli punka i heavy metalu, oczekiwały one swoich ulubionych wykonawców, zaś z niechęcią odnosiły się do grup prezentujących inne nurty muzyczne. Rytuały akceptacji lub odrzucenia można sobie przeciwstawić jako zachowania znajdujące się na przeciwległych typologicznie miejscach swoistej skali emocjonalnych reakcji na działania sceniczne. Publiczność w wyrazisty sposób bowiem dawała do zrozumienia wykonawcom, że są oni scenicznie atrakcyjni lub nie, a ich muzyka może wywoływać silne emocje, powodujące konkretne silne reakcje - akceptacji lub zniechęcenia. 
Dla rytuałów akceptacji były to zachowania:

- skandowanie nazwy grupy występującej (lub dopiero wchodzącej na scenę),

- skandowanie nazwy zespołu w przerwach między utworami i na końcu koncertu,

- taniec pod sceną podczas koncertu (pogo),

- domaganie się dodatkowych utworów (bisy).

Z kolei dla rytuałów odrzucenia typowe były zachowania:

- gwizdy na początku koncertu,

- odwracanie się plecami,

- opuszczanie miejsca koncertu,

- obrzut.

Szczególnym i specyficznym sposobem na wyrażanie dezaprobaty wobec grających była ostatnia z wymienionych, czyli obrzut, a więc rzucanie przez słuchających na scenę różnych przedmiotów (np. plastikowe worki lub butelki $\mathrm{z}$ wodą), ziemi lub trawy wyrwanej z powierzchni stadionu. Rzucane przedmioty w zamierzeniu nie miały wyrządzać krzywdy muzykom, a jedynie pokazać zdecydowanie wrogie wobec nich nastawienie części publiczności. Na ogół było ono manifestacją przynależności subkulturowej młodych ludzi znajdujących się pod sceną - przedstawiciele subkultury punkowej obrzucali grupy heavy metalowe, zaś metalowcy manifestowali swoją niechęć wobec części zespołów punkowych i nowofalowych. Zachowanie to było - ze zrozumiałych względów - zwalczane przez organizatorów Festiwalu.

\section{MIĘDZY NAMI DOBRZE JEST. JAROCIN W LEGENDACH UPAMIĘTNIONY}

Swoista legenda Jarocina składająca się na specyfikę miejsca pamięci to również sfera mitologizacji takich aspektów, jak: szczególne wydarzenia, ludzie istotni dla Festiwalu, specyfika miejsc festiwalowych oraz działania ludzi podczas Festiwalu, składające się na swego rodzaju rytuały związane z FMR. Zjawiska te ujęte jako pewna całość tworzą kolejną sferę mitologizacji działań związanych z koncertami i wspólnotowym przebywaniem młodych ludzi w jednym miejscu. Wymowa tych zjawisk podkreślana jest świadectwami związanymi z wydarzeniami festiwalowymi, a więc filmowymi materiałami archiwalnymi, nagraniami czy wspomnieniami muzyków, organizatorów i fanów obecnych podczas imprezy. 
Można w ten sposób wskazać elementy budujące poczucie wspólnoty, tak cenione przez uczestników i wielokrotnie podkreślane we wspomnieniach. Analizując je z dzisiejszej perspektywy, widać nie tylko substancjalną rolę, jaką odgrywały wówczas - w latach 80., ale także silne emocjonalne nastawienie uczestników wobec nich. To ten właśnie zestaw zjawisk tworzył atmosferę Festiwalu, przetrwał w opowieściach i konsekwentnie włączany jest w budowanie mitologii muzycznego jarocińskiego świata.

Wydarzenia. Mówiąc o istotnych wydarzeniach związanych z Festiwalem, warto wskazać na kilka szczególnych koncertów, które w historii Jarocina zapisały się w sposób szczególny, mianowicie koncerty grup Siekiera (1984), TSA (1981), Dżem (1980), Republika (1985) oraz Dezerter (1984). Wszystkie one przeszły do kronik jarocińskiego Festiwalu jako istotne wydarzenia, w których aspekty artystyczne/estetyczne łączyły się z ważnymi kontekstami społecznymi, tworząc niezwykle silną warstwę emocjonalną - upamiętnioną w mitologii polskiego rocka. Takie emocjonalne nastawienie miało istotny wymiar, po pierwsze, polityczny - koncert TSA odbywał się podczas ciągłych napięć na linii NSZZ „Solidarnośćc - władze państwowe, i chociaż w muzyce zespołu elementy antysystemowe nie występowały jawnie, to koncert ten odczytano jako swego rodzaju młodzieńcze wyzwanie rzucone nie tylko skostniałemu światu rockowych układów (skupionych pod szyldem Muzyka Młodej Generacji), ale jednocześnie jako wyraz i jednoznaczna manifestacja niezwykle silnych emocji wolnościowych, buntowniczych, uosabiających niszczącą system siłę rocka. Po drugie, był to wymiar generacyjny - koncerty punkowych zespołów Siekiera i Dezerter z 1984 roku stały się manifestem pokolenia, buntującego się przeciwko rozrywce lansowanej w mass mediach. Niezwykła energia punkowego przekazu Siekiery oraz jawnie antysystemowa postawa Dezertera ${ }^{2}$ pozwalają uznać, że podczas tych wydarzeń zamanifestowano relatywnie klarowny podział świata na kategorie „my - oni”, w którym subkulturowa młodzież zintegrowała się wokół - dosłownie - bezczelnej punkowej estetyki, buntując się przeciwko zastanym schematom promowanym w sposób zinstytucjonalizowany.

2 Wokalista zespołu Skandal wdał się na scenie w ostrą kłótnię z Walterem Chełstowskim i obsługą Festiwalu, co mogło doprowadzić do przerwania koncertu i zamieszek z pilnującymi porządku siłami milicyjnymi i ZOMO (oczekującymi w pobliskim lasku na rozwój wydarzeń). 
Ludzie. Na swoistą mitologię Festiwalu składają się także istotne dla niego osoby, takie jak: Walter Chełstowski, Marcin Jacobson, Wojciech Korzeniowski, Jacek Sylwin czy Paweł Sito, a więc organizatorzy, promotorzy, dziennikarze, którzy nie tylko pracowali przy imprezie w charakterze organizatorów, ale także brali udział w promowaniu wydarzenia, kwalifikowania zespołów oraz - co także niezwykle ważne - relacjonowania tego, co na festiwalu miało miejsce. Dzięki tym działaniom zespoły i soliści występujący podczas festiwali mogli liczyć na zainteresowanie publiczności, a to z kolei tworzyło w kręgach undergroundowej młodzieży odpowiednią atmosferę wokół imprezy, co przekładało się na frekwencję w kolejnych latach.

Miejsca. Mitologię Festiwalu w Jarocinie tworzyły także miejsca, takie jak: JOK, amfiteatr, stadion, pole namiotowe, domki jednorodzinne. Były to najważniejsze fizyczne przestrzenne lokalizacje, w których odbywały się działania podmiotów zaangażowanych w Festiwal. Ich różnorodny charakter oznacza, że impreza ta miała kompleksowy charakter - składały się na nią wielopoziomowe i przenikające się działania codziennych aktywności, związane z konsumpcją treści festiwalowych. To miejsca rozrywki i odpoczynku, a więc zaspakajające najważniejsze potrzeby młodych ludzi w okresie wakacyjnym.

Działania. Większość działań, które towarzyszą Festiwalowi, to działania rytualne, takie jak: kwalifikacje z kaset, eliminacje w JOK, koncerty, konkurs/ zwycięzcy, publiczność (pogo, młyn), rytuał akceptacji grających zespołów (gwizdy na początku koncertu, obrzut), kłopoty z cenzurą. Zostały one wskazane i skomentowane powyżej w kontekście rytualnych zachowań trzech istotnych grup ludzi zaangażowanych w życie festiwalowe: organizatorów, muzyków i publiczność.

\section{NOWA SFERA MITOLOGIZACJI JAROCINA: ŻYCIE PO ŻYCIU}

Uznać można, że meta-miejsce pamięci funkcjonuje w wielu wymiarach, wielu środowiskach i rozpowszechniane jest za pomocą wielu mediów. Nie inaczej jest z FMR, który jest tematem opracowań, wspomnień i działań instytucjonalnych wykazujących jego istotną rolę w kontekście tworzenia antysystemowych działań alternatywnej młodzieży. Co istotne, narracja na temat Jarocina jest przedmiotem współczesnej debaty - opowieść o „oazie wolności” pośrodku 
socjalistycznego reżimu jest zinstytucjonalizowana jako zjawisko opisujące Jarocin z dzisiejszej perspektywy i znaleźć je można we współcześnie wydawanych materiałach i przekazach. Mamy zatem do czynienia ze swoistym „życiem po życiu” Jarocina, manifestowanym poprzez: media (książki, filmy, strony www poświęcone FMR); instytucje (muzeum Spichlerz Polskiego Rocka, nowy festiwal w Jarocinie); pamięć zbiorową (wspomnienia, rozmowy, seminaria, ruch naukowy dotyczący Jarocina jako ważnego wydarzenia w biografii poszczególnych jednostek i w zbiorowej biografii pokolenia dojrzewającego w połowie lat 80. XX wieku, jak choćby organizowane na Uniwersytecie Mikołaja Kopernika sesje i konferencje naukowe poświęcone polskiemu rockowi oraz wybranym zjawiskom tego okresu).

\section{UWAGI KOŃCOWE}

Jarocin uznać można za miejsce pamięci, bowiem wyznacza ramy zbiorowej pamięci i pozwala na wpisanie go w kulturę buntu przeciw oficjalnej władzy lat 80., a jednocześnie - żyją świadkowie tych wydarzeń, którzy z perspektywy czasu potrafią dostrzec istotę Festiwalu i jego wagę dla polskiej kultury. FMR jest miejscem pamięci wyznaczonym konkretnymi wydarzeniami, zjawiskami, działaniami ludzkimi i datami w historii, a jednocześnie jest fenomenem na tyle pojemnym i elastycznym, że wiele środowisk może nadawać mu odpowiednią interpretację i formować go pod względem zawartości. We wspomnieniach i opowieściach o Jarocinie otrzymujemy bowiem różnorodne narracje, podkreślające różne jego aspekty, łączące jednak wiele wspólnych tropów, z których poczucie wspólnotowości, buntownicze nastawienie wobec starszych generacji oraz emocje towarzyszące przeżyciom estetycznym (grupowo przeżywana muzyka) są najważniejszymi elementami tworzącymi tkankę miejsca pamięci, jakim jest Jarocin.

Koncepcja miejsc pamięci wpisuje się w rozważania podjęte w niniejszym artykule - złożona symbolika funkcjonowania pamięci społecznej i kulturowej nakłada się na jednostkowe wrażenia odbite w pamięci ludzi, często fragmentaryczne i dalekie od zgodności z rzeczywistością. Wspomnienia z dzieciństwa czy wieku dorastania uwikłane są każdorazowo w konteksty społeczne (na przykład dotyczące relacji rodzinnych) i funkcjonują jako fragmentaryczne wyobrażenia na temat tego, co postrzegane było przez człowieka jako element realnego doświadczenia. Tym samym zdarzenia, impresje, obrazy w pamięci, 
kolory, dźwięki stają się prywatnymi miejscami pamięci, nabierającymi mocy symbolicznego wyjaśniania świata. Zjawiska te odnoszą się, co zrozumiałe, także do kwestii muzycznych, sprawiając, że miejscami pamięci będą realnie istniejące piosenki, płyty, audycje radiowe i telewizyjne, artykuły prasowe, koncerty, ale także wrażenia towarzyszące ich konsumpcji - sytuacje odbioru, skojarzenia z czynnościami, miejscami i ludźmi, pojawiającymi się podczas obcowania z muzyką.

I jeszcze jedna kwestia dotycząca FMR w Jarocinie. Możemy Festiwal dziś postrzegać jako wysoce substancjalne doświadczenie formacyjne generacyjnie, oddziałujące w sposób grupotwórczy dla wielu środowisk (przede wszystkim subkulturowych) i wyznaczające optykę interpretacyjną dla wydarzeń, zjawisk, biografii etc. Dla poprzednich pokoleń wskazać możemy takie wydarzenia, jakimi przykładowo były powstanie warszawskie, październik 1956, marzec 1968, sierpień 1980, a więc istotne wydarzenia z polskiej historii, wpisane na stałe w pamięć zbiorową (co naturalne w tej roli nie muszą występować jedynie wydarzenia o jednoznacznie politycznym charakterze, jednak najczęściej właśnie one są w tej roli wskazywane - poprzez łatwość obserwowania wspólnotowego działania, wspólnych emocji i przeżyć doświadczanych przez liczne jednostki). Jarociński Festiwal z lat 1983-1986 pełni tę samą funkcję: pokolenie dojrzewające w połowie lat 80 . może w nim znaleźć taki właśnie punkt odniesienia, tworzący swoiste ramy, w których można interpretować rzeczywistość (i tę historycznie rozumianą, i tę codzienną - współczesną) poprzez odniesienie się do zbiorowych doświadczeń pokoleniowych.

\section{BIBLIOGRAFIA:}

Assman, J. (1992). Cultural Memory and Early Civilization: Writing, Remembrance, and Political Imagination. Cambridge: Cambridge University Press.

Bell, C. (1997). Ritual Perspectives and Dimensions. Oxford, New York: Oxford University Press.

Delaperrière, M. (2013). „Miejsca pamięci czy pamięć miejsc?”. Ruch Literacki, LIV/2013, (z.1).

Gnoiński, L., Gajczak, M. (2016). Jarocin. Po co wolność?. Barton Film.

Grabowski, K. (2016). „Życie na barykadzie”. Rozmawia Mirosław Pęczak. Polityka, 28/2016, s. 74-76.

Halbwachs, M. (1925). Les Cadres sociaux de la memoire. Paris: Librairie Félix Alcan.

Hastrup, K. (1997). „Przedstawianie przeszłości. Uwagi na temat mitu i historii”. Konteksty. Polska Sztuka Ludowa, 1-2/1997, s. 22-28. 
Lowenthal, D. (1988). Past is the Foreign Country. Cambridge: Cambridge University Press.

Müller, J.-W. (2002). Introduction: The Power of Memory, the Memory of Power and the Power Over Memory. W: J.-W. Müller (red.), Memory and Power in Post-War Europe: Studies in the Presence of the Past. Cambridge: Cambridge University Press.

Nora, P. (1984). Les Lieux de memoire (vol. 1). Paris: Gallimard.

Nora, P. (1989). „Between Memory and History: Les Lieux de Mémoire”. Representations 26, Spring 1989, s. 7-25.

Nora, P. (1996). From lieux de mémoire to realms of memory. W: P. Nora, L.D. Kritzman (red.), Realms of Memory: Rethinking the French Past. Vol. 1: conflicts and divisions. New York and Chichester: Columbia University Press.

Plate, L., Smelik, A. (2009). Technologies of Memory in the Arts: An Introduction. W: L. Plate, A. Smelik (red.), Technologies of Memory in the Arts. New York: Palgrave Macmillan.

Schnapp, A. (1996). The Discovery of the Past. The Origins of Archaeology. London: British Museum Press.

Turner, V. (2010). Proces rytualny. Struktura i antystruktura. Warszawa: Państwowy Instytut Wydawniczy. 